\title{
Temporal Monitoring and Assessment of Inorganic Nitrogen Content of Soil due to Nitrogen Fertilizers and their Related Cytotoxic Effects
}

\author{
K. Arora, S. Verma
}

10.18805/ag.D-5301

\begin{abstract}
Background: Indian economy is largely based on agriculture. Major share of agricultural investments goes into chemical fertilizers. Nitrogen $(\mathrm{N})$ fertilizers are used in fields to enhance the crop yield. Most of the reports are based on growth related data, morphological and yield related data but very few reports reveal the facts about genotoxic and cytotoxic effects of these fertilizers. Therefore, the present communication is an attempt in the aforesaid direction.

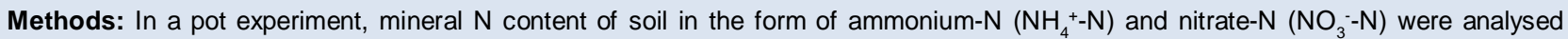
at regular interval of 5 days till 30 days after treatment (DAT). On the corresponding days root tip assay was done for cytotoxic analyses and also the temporal changes in $\mathrm{NH}_{4}{ }^{+}-\mathrm{N}$ and $\mathrm{NO}_{3}{ }^{-} \mathrm{N}$ contents were observed.

Result: In the Ammonium nitrate treatments, higher mitotic index (MI\%) percentages were obtained. While for the Urea, $\mathrm{NH}_{4}^{+}-\mathrm{N}$ content and MI were found to have a positive correlation. Also, it was found that there is an optimum ratio of $\mathrm{NH}_{4}{ }^{+}-\mathrm{N}^{-}$and $\mathrm{NO}_{3}{ }^{-} \mathrm{N}$ in each treatment at which the MI\% was the maximum. The study gives an interesting insight for the possible cytotoxic effects of the $\mathrm{N}$ fertilizers.

Key words: Ammonium and nitrate ratio, Cytotoxic, Nitrogen fertilizers.
\end{abstract}

\section{INTRODUCTION}

Soil is a natural pool of nutrients and its fertility is reflected by the quantity of different nutrients and their relative ratios. Most of the soils either do not have optimum nutrient contents or get deprived due to numerous reasons like plant uptake, volatilization, leaching, soil erosion etc. Hence, fertilizer supplementation at regular intervals is necessary to provide essential elements and nutrients in a readily available form for the optimum plant growth. Such supplementation works only when the fertilizers are of balanced composition and fertilization is done at right time and in right amount (Bindraban et al., 2015). Among various fertilizers, the global consumption of nitrogen $(\mathrm{N})$ fertilizers is always high and about $70 \%$ of soil $\mathrm{N}$ for plants is provided by inorganic fertilizers. In the soil, inorganic $\mathrm{N}$ exist in two major forms, viz. ammonium nitrogen $\left(\mathrm{NH}_{4}{ }^{+} \mathrm{N}\right)$ and nitrate nitrogen $\left(\mathrm{NO}_{3}-\mathrm{N}\right)$. Therefore, $\mathrm{N}$ fertilizers in market are either ammonium based (ammonium sulphate, urea etc.), or nitrate based (calcium nitrate, potassium nitrate, etc.) while some of these are double salt based like ammonium nitrate which provides both the inorganic forms.

Plants show selective uptake of the different $\mathrm{N}$-sources and consequent varied responses which also may be affected by the interaction between soil physico-chemical properties and the environmental factors. Also, this selective uptake of ions by the plants results into different effects on the soil environment especially rhizosphere. Based on the variation in chemical properties of these two inorganic $\mathrm{N}$, their initial fate in soil is different ( $\mathrm{Li}$ et al., 2012). As plants uptake $\mathrm{NH}_{4}^{+}$, protons $\left(\mathrm{H}^{+}\right)$are released which make the $\mathrm{pH}$
Department of Botany, In Vitro Culture and Plant Genetics Unit, Faculty of Science, University of Lucknow, Lucknow-226 007, Uttar Pradesh, India.

Corresponding Author: Kavita Arora, Department of Botany, National P.G. College, Lucknow-226 001, Uttar Pradesh, India.

Email: drkarora17@gmail.com

How to cite this article: Arora, K. and Verma, S. (2021). Temporal Monitoring and Assessment of Inorganic Nitrogen Content of Soil due to Nitrogen Fertilizers and their Related Cytotoxic Effects. Agricultural Science Digest. DOI: 10.18805/ag.D-5301.

Submitted: 15-01-2021 Accepted: 15-11-2021 Online: 09-12-2021

of rhizosphere acidic, whereas nitrate uptake shifts the $\mathrm{pH}$ towards alkalinity. In contrast to nitrate, plants cannot safely store elevated levels of ammonium in their cells which also has subsequent toxic effects (Esteban et al., 2016). Earlier reports certify this fact by suggesting that when $\mathrm{NH}_{4}{ }^{+}$is used as the chief $\mathrm{N}$ source, most of plant species develop toxicity symptoms (Kronzucker et al., 2001; Rogato et al., 2010). On the other hand, nitrate toxicity occurs in plants when higher quantities of nitrates are present in soil (Britto and Kronzucker, 2005; Okushima et al., 2011). There are only handfuls of reports that correlate the effect of external ammonium and nitrate contents to the toxic effects at cellular level (Qin et al., 2011; Arora et al., 2014; Verma et al., 2016). But there are plenty of reports revealing that plant species grow well if $\mathrm{NH}_{4}^{+}-\mathrm{N}$ and $\mathrm{NO}_{3}^{-}-\mathrm{N}$ are supplied in an appropriate ratio (Kronzucker et al., 1999; Babourina et al., 2007; BarYosef et al., 2009). In view of above cited literature, we have 
Temporal Monitoring and Assessment of Inorganic Nitrogen Content of Soil due to Nitrogen Fertilizers and their Related...

selected two chemically different $\mathrm{N}$-fertilizers, i.e., urea $\left(\mathrm{NH}_{4}{ }^{+}-\mathrm{N}\right.$ source) and ammonium nitrate $\left(51 \% \mathrm{NO}_{3}-\mathrm{N}\right.$ and $49 \% \mathrm{NH}_{4}{ }^{+} \mathrm{N}$ ) and assessed the temporal changes in inorganic $\mathrm{N}$-contents in soil and their effects at cellular level in plants. Various workers have earlier taken up this aspect, but their analytical approach is different and majorly based on morphological data, growth analysis and yield (Yin et al., 2017; Fashaho et al., 2020; Kumari et al., 2021). To the best of our knowledge, there are very few reports suggesting the genotoxic and cytotoxic effects of fertilizers (Khaldi et al., 2012; Verma and Srivastava, 2017). Hence, considering it an issue of serious concern, the present study is in continuation with our previous works on $\mathrm{N}$ - fertilizers (Arora et al., 2014; Verma et al., 2016; Verma and Srivastava, 2018a).

Allium cepa root tip bioassay is used to determine the effects of two $\mathrm{N}$-fertilizers at cellular level and any evident cytotoxic risks associated with it. Earlier, this assay system was used for environmental and toxicological monitoring (Fiskesjo, 1985; Verma and Srivastava, 2018a), but in the present times it has also found application as bioindicator of genotoxicity (Firbas and Amon, 2013). This system bears the merits of providing a rapid screening for the causative pollutants, toxicants, contaminants etc.

\section{MATERIALS AND METHODS}

The experiment was conducted in the year 2016-2017 at In Vitro Culture and Plant Genetics Unit, Department of Botany, Lucknow University, Lucknow.

\section{Soil sampling}

Collection of soil for the experiment was done from University garden situated at $26^{\circ} 51^{\prime} 53^{\prime \prime} \mathrm{N}$ latitude and $80^{\circ} 56^{\prime} 15^{\prime \prime} \mathrm{E}$ longitude at a depth of $30 \mathrm{~cm}$ from an area that was not fertilized. One $\mathrm{kg}$ sieved soil was air-dried and placed in 6" pots. The physico-chemical properties of the soil used are given in Table 1.

\section{Application of fertilizers}

Soil in pots was treated with selected $\mathrm{N}$-fertilizers, urea and ammonium nitrate. Three treatments as Control (T1) which was without any additive, soil supplemented with urea at the rate of $200 \mathrm{mg} \mathrm{N} \mathrm{kg}^{-1}$ soil (T2) and soil supplemented with ammonium nitrate at the rate of $200 \mathrm{mg} \mathrm{N} \mathrm{kg}^{-1}$ soil (T3) were made. Three replicates, consisting of 3 pots each were taken per treatment i.e. 9 pots per treatment.

\section{Estimation of inorganic $\mathbf{N}$ nutrients}

Temporal monitoring of inorganic $\mathrm{N}$ (Ammonium-N $\left(\mathrm{NH}_{4}{ }^{+}\right.$ $\mathrm{N})$ and nitrate- $\mathrm{N}\left(\mathrm{NO}_{3}-\mathrm{N}\right)$ contents) was done on $1,5,10$, $15,20,25$ and 30 days after treatment (DAT). The ratio

Table 1: Physico-chemical properties of the soil.

\begin{tabular}{lc}
\hline Soil properties & Values \\
\hline $\mathrm{pH}$ & 7.54 \\
Organic matter & $2.40 \%$ \\
$\mathrm{NH}_{4}+-\mathrm{N}$ & $18.00 \mathrm{mg} \mathrm{kg}^{1}$ soil \\
$\mathrm{NO}_{3}-\mathrm{N}$ & $2.34 \mathrm{mg} \mathrm{kg}^{1}$ soil \\
\hline
\end{tabular}

between $\mathrm{NH}_{4}^{+}-\mathrm{N}$ and $\mathrm{NO}_{3}^{-}-\mathrm{N}$ content was calculated as $\mathrm{NH}_{4}^{+}{ }_{-}^{-}$ $\mathrm{N}$ per unit $\mathrm{NO}_{3}^{-}-\mathrm{N}$.

\section{Estimation of $\mathrm{NH}_{4}{ }^{+}-\mathrm{N}$}

Nessler's method was used to analyse $\mathrm{NH}_{4}{ }^{+}-\mathrm{N}$ in soil samples (Peech et al., 1947). Soil suspension was prepared by using $100 \mathrm{~g}$ of soil sample, taken in a conical flask and then $200 \mathrm{ml}$ of acidified $\mathrm{NaCl}$ solution was added to it. The suspension was vigorously shaken for about $30 \mathrm{~min}$. then filtered. The leachate obtained was taken and volume was made up to $100 \mathrm{ml}$ using acidified $\mathrm{NaCl}$. Further $\mathrm{NH}_{4}^{+}-\mathrm{N}$ was determined using Nessler's method. The transmission (\%) of the solution was read in a spectrophotometer at $410 \mathrm{~nm}$.

\section{Estimation of $\mathrm{NO}_{3}^{-}-\mathrm{N}$}

Phenoldisulphonic method (Bremner, 1965) was adopted to analyse the $\mathrm{NO}_{3}^{-}-\mathrm{N}$ in soil samples. For soil suspension, $50 \mathrm{~g}$ of soil was taken and $250 \mathrm{ml}$ of extraction solution (1 part of $\mathrm{CuSO}_{4}$ and 5 parts of $\mathrm{Ag}_{2} \mathrm{SO}_{4}$ ) was added to it. The soil suspension was shaken for $10 \mathrm{~min}$ and then $0.4 \mathrm{~g} \mathrm{Ca}$ $(\mathrm{OH})_{2}$ was added. Further shaking of 5 min was done and then $1 \mathrm{~g}$ of $\mathrm{MgCO}_{3}$ was added. Suspension was then filtered. Ten $\mathrm{ml}$ of clear filterate was taken and evaporated to dryness in evaporating dish. Three $\mathrm{ml}$ of phenol disulfonic acid was added and it was left for $10 \mathrm{~min}$. Then $15 \mathrm{ml}$ of cold water was added to it. Sodium hydroxide (12\%) was added slowly to the solution until it became distinctly alkaline which was indicated by the development of yellow color. Finally, $3 \mathrm{ml}$ more of sodium hydroxide solution was added to it. The transmission (\%) of the solution was read in a spectrophotometer at $420 \mathrm{~nm}$.

\section{Cytotoxicity analysis}

Healthy onion bulbs of medium size were properly cleaned. Their outer scales and brownish bottom plates were removed with a precaution of not damaging the ring of root primordia. The experiment was designed to run in three replicates with each replicate consisting of three pots and each pot had one onion bulb placed in the centre. The same soil was used for sowing fresh onion bulbs at 1, 5, 10, 15, 20, 25 and 30 DAT. Roots were harvested on day 3 of each sowing.

For cytological analysis, roots were fixed in Carnoy's fluid (1 part glacial acetic acid +3 part ethanol) for $24 \mathrm{hrs}$ and then preserved in $70 \%$ ethanol. Fixation and slides preparations were done by following modified protocol of Sharma and Sharma (1980). The mitotic analysis was done on temporary slides. The dividing cells were observed under microscope. Approximately 500 cells from at least 5 random root meristems per replicate were screened to determine the mitotic index percentage (Ml\%).

$$
\mathrm{MI}(\%)=\frac{\text { Total number of dividing cells }}{\text { Total number of cells observed }} \times 100
$$

\section{Statistical analysis}

The data obtained was evaluated statistically with the statistical software SPSS for Windows ver. 15.0, (SPSS Inc., Chicago, III., USA). The data was analysed by One-way 
analysis of variance (ANOVA) followed by Duncan's multiple range test (DMRT) and significance was measured at $p \leq 0.05$. The correlation amongst the parameters was assessed by Pearson Correlation Coefficient analysis (Zou et al., 2003).

\section{RESULTS AND DISCUSSION}

The data was collected every 5 DAT till one month. Control (T1) had very low amount of $\mathrm{NH}_{4}^{+}-\mathrm{N}$ and $\mathrm{NO}_{3}{ }^{-} \mathrm{N}$ as compared to other treatments (Fig 1a). Evaluation of the two treatments,

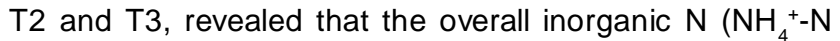
and $\mathrm{NO}_{3}^{-} \mathrm{N}$ ) content range was higher in $\mathrm{T} 3$ treatment.
Temporal variations in $\mathrm{NH}_{4}{ }^{+}-\mathrm{N}$ and $\mathrm{NO}_{3}{ }^{-} \mathrm{N}$ contents in individual treatments, were significantly different.

\section{Temporal monitoring of inorganic $\mathbf{N}$ content}

In case of $\mathrm{T} 1$, soil $\mathrm{NH}_{4}^{+}-\mathrm{N}$ content followed a continuous decrease since 1 DAT (Fig 1a). Treatment T2 showed an increase in soil $\mathrm{NH}_{4}{ }^{+} \mathrm{N}$ till 5 DAT and reached up to $80 \mathrm{mg}$ $\mathrm{kg}^{-1}$, then between 10 DAT to 30 DAT a decline from $74 \mathrm{mg}$ $\mathrm{kg}^{-1}$ to $18 \mathrm{mg} \mathrm{kg}^{-1}$ was observed in the content (Fig $1 \mathrm{~b}$ ). In T3, periodic fluctuations were observed in the amount of $\mathrm{NH}_{4}{ }^{+} \mathrm{N}$ i.e., no continuum in the trend was observed. There

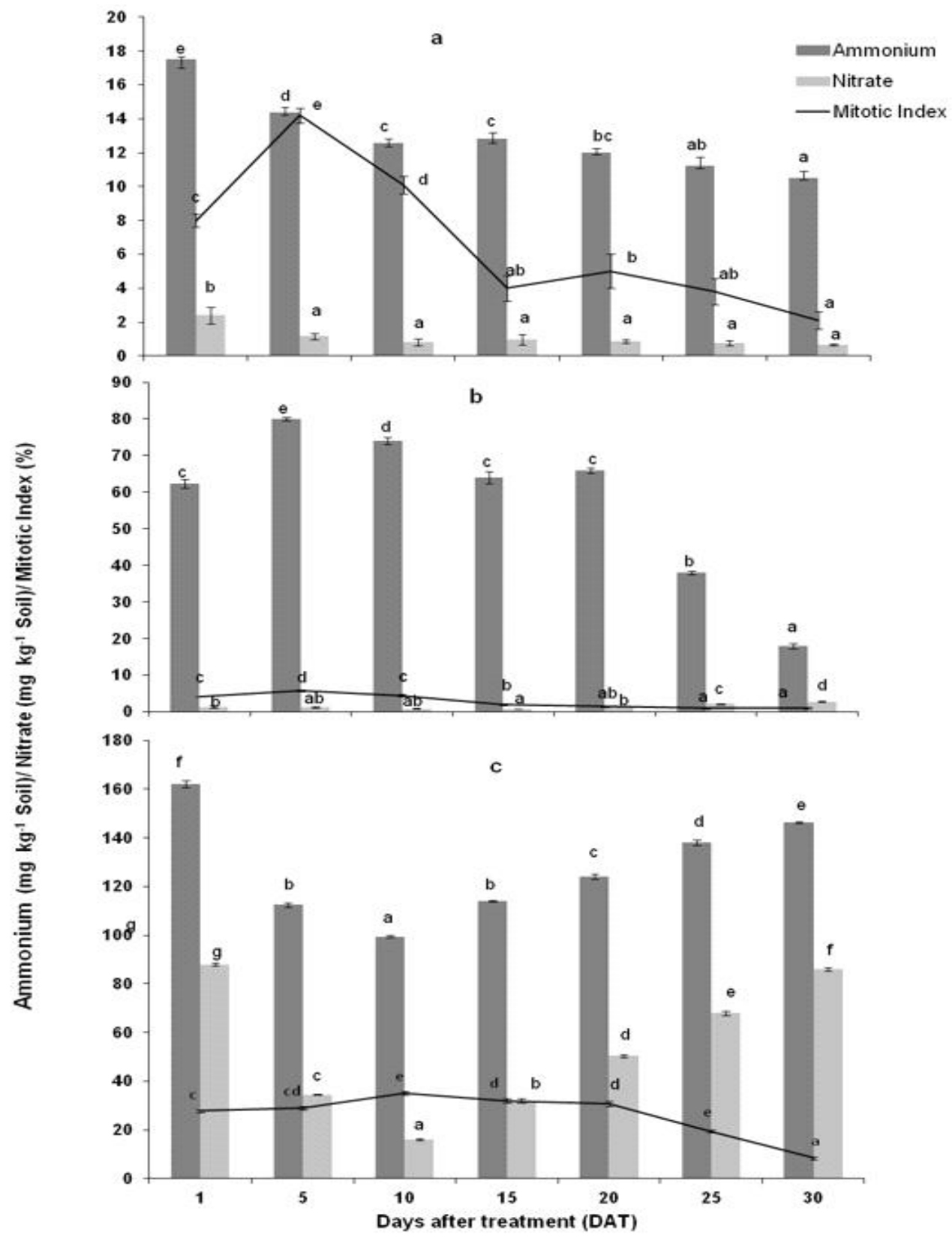

Fig 1: Variations in mitotic indices in (a) Control (T1), (b) Urea (T2) and (c) Ammonium nitrate (T3) with $\mathrm{NH}_{4}{ }^{+}-\mathrm{N}^{2}$ and $\mathrm{NO}_{3}{ }^{-} \mathrm{N}$ contents at regular intervals of time. Data are means $\pm \mathrm{SE}$ of three replicates. Bars with different letters are signiûcantly different at $p \leq 0.05$ as determined by Duncan's multiple range test. 
was a decrease from $162.2 \mathrm{mg} \mathrm{kg}^{-1}$ on 1 DAT to $99.5 \mathrm{mg} \mathrm{kg}^{-1}$ as on 10 DAT then again, increases till 30 DAT (Fig 1c). Regarding $\mathrm{NO}_{3}^{-}-\mathrm{N}$ content, $\mathrm{T} 1$ showed a continuous decrease till 30 DAT. Urea (T2) showed a contrary result to $\mathrm{NH}_{4}^{+}-\mathrm{N}$, from 1 DAT to 15 DAT, there was a drop and then elevation in $\mathrm{NO}_{3}^{-}-\mathrm{N}$ content. This increase in $\mathrm{NO}_{3}^{-}-\mathrm{N}$ could be due to nitrification process. In case of $\mathrm{T3}, \mathrm{NO}_{3}^{-}-\mathrm{N}$ content of the soil also followed similar trend as that of $\mathrm{NH}_{4}{ }^{+} \mathrm{N}$, that is, it was observed to be $88 \mathrm{mg} \mathrm{kg}^{-1}$ initially on 1 DAT and then a decline was obtained till 10 DAT. There was a continuous rise of nitrate amount from 15 DAT to 30 DAT. A correlation analysis showed that, $\mathrm{NH}_{4}{ }^{+}-\mathrm{N}$ and $\mathrm{NO}_{3}{ }^{-} \mathrm{N}$ contents in various treatments were almost ideally correlated with each other, that is, in T1 and T3 an ideal positive correlation with $r=0.95$ and 0.98 respectively, at $p \leq 0.05$, 0.01 and 0.001 was obtained where as in T2 a negative correlation with $r=-0.92$ at $p \leq 0.05$ and 0.01 was obtained (Fig 2a-c).

\section{Relation of MI with inorganic N content}

Cytological analysis of root meristems revealed that in T1 and T2, there was an increase in MI from 1 DAT to 5 DAT which then decreased thereafter till 30 DAT (Fig 1a and b). In case of T3, from 1 DAT to 10 DAT, MI increased and then decreased till 30 DAT (Fig 1c). Maximum MI of $35 \%$ on 10 DAT was observed in T3, whereas in T2 treated roots maximum $\mathrm{MI}$ was $5.8 \%$ on 5 DAT which was even lower than $\mathrm{T} 1$. In case of $\mathrm{T} 2$, changes in $\mathrm{NH}_{4}{ }^{+} \mathrm{N}$ content in soil was significantly correlated with $\mathrm{Ml}, r=0.76$ at $p \leq 0.05$, where as in $\mathrm{T} 3, \mathrm{NO}_{3}^{-}-\mathrm{N}$ showed a significant negative correlation with $\mathrm{MI}, r=-0.74$ at $p \leq 0.05$ and $\mathrm{NH}_{4}{ }^{+} \mathrm{N}$ did not show any significant relation with $\mathrm{MI}$.

\section{Relation of $\mathrm{MI}$ with $\mathrm{NH}_{4}{ }^{+}-\mathrm{N}$ and $\mathrm{NO}_{3}-\mathrm{N}$ ratio}

Data for ratio of $\mathrm{NH}_{4}^{+}-\mathrm{N}$ to one unit of $\mathrm{NO}_{3}{ }^{-} \mathrm{N}$ was analysed in each treatment and varied trends were obtained, viz. in T1 ratio increased till 10 DAT then decreased till 20 DAT and again increased till 30 DAT. In T3, it initially increased till 10 DAT then kept on decreasing till 30 DAT. In urea (T2), initially the ratio increased till 15 DAT and then reduced up till 30 DAT. In the treatments, ratio at which MI\% was at its peak, considered to be the optimum ratio for that particular treatment. In T1 on 5 DAT, $14.2 \% \mathrm{Ml}$ at ratio 12.52, in T2 on $5 \mathrm{DAT}, 5.8 \% \mathrm{MI}$ at ratio 64.5 whereas in T3, highest of all MI values that is $35 \%$ at ratio 6.22 was obtained on 10 DAT (Fig 3). These can be considered as optimum ratios because beyond these ratios lower values of Ml were observed in all the treatments. No significant correlation between ratio and MI was observed in any of the treatments.

Urea undergoes hydrolysis by the action of urease and releases $\mathrm{NH}_{4}{ }^{+}$and carbon dioxide, thereby providing $\mathrm{NH}_{4}{ }^{+}$ as sole $\mathrm{N}$ source for plant, whereas ammonium nitrate being the salt of strong acid undergoes ionization and releases $\mathrm{NO}_{3}{ }^{-}$and $\mathrm{NH}_{4}{ }^{+}$ions. Final fate of $\mathrm{NH}_{4}{ }^{+}$(from either source) is to undergo nitrification and get converted into nitrates. This fact is in consonance with our results wherein T2, temporal changes in $\mathrm{NH}_{4}{ }^{+}-\mathrm{N}$ and $\mathrm{NO}_{3}{ }^{-} \mathrm{N}$ contents are negatively correlated but in T3 a positive correlation was obtained. Both the ions after immediate ionization are available for plant in case of double salt fertilizer ammonium nitrate. This is a known fact that plants can absorb and utilize $\mathrm{N}$ as $\mathrm{NH}_{4}{ }^{+}$and $\mathrm{NO}_{3}{ }^{-}$present in soil solution (Oh et al., 2008), which then within plant undergoes various processes of assimilation, transformation and mobilization (Oh et al., 2008). In present analysis, in case of $\mathrm{T}_{2} \mathrm{NH}_{4}^{+}-\mathrm{N}$ levels are significantly correlated with $\mathrm{Ml}$ showing $\mathrm{NH}_{4}{ }^{+}-\mathrm{N}$ is the sole $\mathrm{N}$-source utilized by plants initially. Among the treatments, T2 seems to cytotoxic. Initially till 5 DAT, MI is increasing but 10 DAT MI showed a decline due to higher $\mathrm{NH}_{4}{ }^{+} \mathrm{N}$ accumulation. Also, previous studies by the same group,
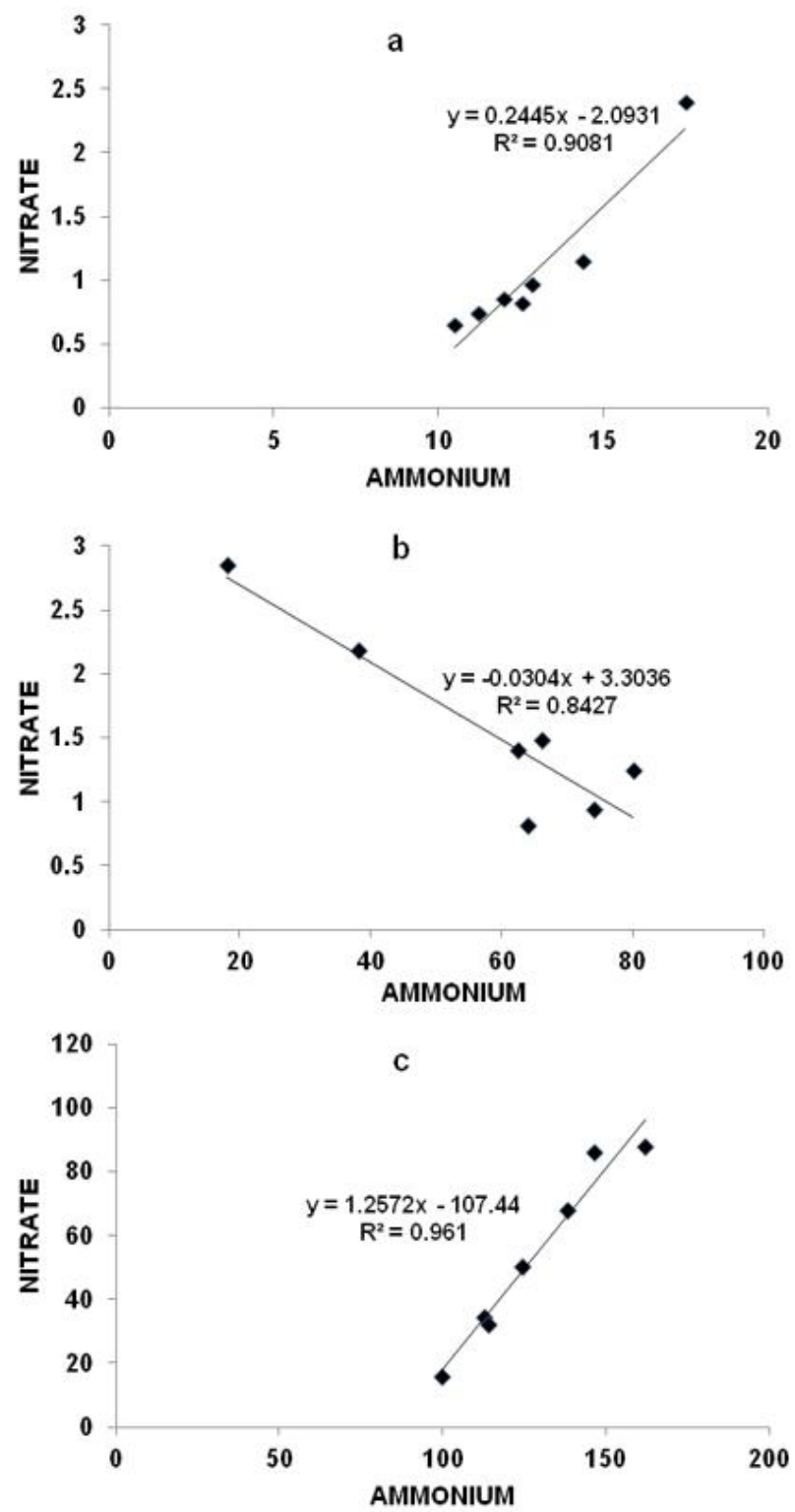

Fig 2: Relationship between $\mathrm{NH}_{4}{ }^{+}-\mathrm{N}$ and $\mathrm{NO}_{3}{ }^{-} \mathrm{N}$ contents from 1 DAT to 30 DAT in (a) Control (T1), (b) Urea (T2) and (c) Ammonium nitrate (T3). 
on the fertilizer has revealed that it is not only mitodepressive but also promotes mitotic anomalies especially interphase anomalies (Verma et al., 2016). The reasons may be toxicity of $\mathrm{NH}_{4}{ }^{+} \mathrm{N}$ and its accompanied effects. Mitotic index is the measure of cell division and growth and is a potential parameter for cytotoxicity (Fiskesjo, 1985; Bianchi et al., 2016), further it has also been regarded as a cytotoxicity biomarker (Verma and Srivastava, 2018b). In view of cited literature low $\mathrm{MI}$ in present case reflect the cytotoxic effects in plant. As $\mathrm{NH}_{4}^{+}-\mathrm{N}$ is taken up by plants it releases protons in soil reducing the $\mathrm{pH}$ of soil which causes $\mathrm{NH}_{3}{ }^{+}$to bind with protons and form $\mathrm{NH}_{4}^{+} \mathrm{N}$ ions, this build-up of $\mathrm{NH}_{4}^{+}-\mathrm{N}$ concentration in soil hampers the uptake of other ions and induces salinity stress (Cabrera, 2001). In a recent report, it has been shown that higher levels of ammonium in rice plants, induces reactive oxygen species (ROS) mediated reactions (Yang et al., 2020). The excessive generation of ROS in plants is due to environmental stress like drought, salinity (Mittler, 2002) in response to ammonium toxicity. Further the results can be supported by the previous reports of Babourina et al. (2007), Bittsánszky et al. (2015), suggesting the $\mathrm{NH}_{4}^{+}-\mathrm{N}$ toxicity in plants when $\mathrm{NH}_{4}{ }^{+} \mathrm{N}$ is the sole $\mathrm{N}$ source. Their accumulation in soil causes acidification of soil and when they accumulate in plant cells acidification of cytosol occurs. Various morphotoxic and cytotoxic effects of $\mathrm{NH}_{4}{ }^{+} \mathrm{N}$ in plants is well known in literature as shown by Liu et al., (2013) and Arora et al., (2014). Toxicity of $\mathrm{NH}_{4}{ }^{+}-\mathrm{N}$ caused inhibition of primary root growth by inhibiting cell elongation and division and even led to root cell death as reported by Qin et al. (2011). It also causes disturbed phytohormone and polyamine levels (Britto and Kronzucker, 2013).

Mitotic index seems to be higher in case of T3 as both the forms of nitrogen, can be utilized by the plants. Though in case of T3, plants get both forms of $\mathrm{N}$ but the peak of MI was obtained when the ratio of the two ions was optimum i.e., at 10 DAT. It is possible that a lower or higher ratio between the two ions may not be effective for the root growth; therefore low values of $\mathrm{Ml}$ were obtained. When mixed $\mathrm{N}$ nutrition is supplied to the plants, protons are generated during $\mathrm{NH}_{4}{ }^{+}-\mathrm{N}$ assimilation which can be utilized for $\mathrm{NO}_{3}{ }^{-} \mathrm{N}$ reduction hence regulate the intercellular $\mathrm{pH}$ ( $\mathrm{Li}$ et al., 2012). Rhizospheric $\mathrm{pH}$ got neutralized when both the forms of $\mathrm{N}$ were supplied as reported by Hinsinger et al. (2003). Nitrogen as $\mathrm{NH}_{4}{ }^{+}$can lead to release of protons which can decrease the rhizospheric $\mathrm{pH}$. At low $\mathrm{pH}$ there is more ammonium formation as reaction proceeds in forward direction. This may lead to accumulation of ammonium in soil because of limited uptake by plant. Whereas $\mathrm{N}$ as $\mathrm{NO}_{3}$. can take up protons from the rhizosphere, which causes an increase in the rhizospheric $\mathrm{pH}$. Being opposite charge ion, nitrate protects the root cells from $\mathrm{NH}_{4}^{+}$induced depolarization of plasma membrane by charge balancing (Wang et al., 1993). It causes decrease in internal ratio of cations and anions in plants (Britto and Kronzucker, 2002). Kronzucker et al., (1999) concluded in their study on $\mathrm{NO}_{3}^{-}$$\mathrm{NH}_{4}{ }^{+}$synergism in rice that presence of $\mathrm{NO}_{3}$ - enhanced the $\mathrm{NH}_{4}{ }^{+}$fluxes, $\mathrm{NH}_{4}{ }^{+}$metabolism and cytosolic $\mathrm{NH}_{4}{ }^{+}$ accumulation. Whereas presence of $\mathrm{NH}_{4}{ }^{+}$repressed the $\mathrm{NO}_{3}{ }^{-}$ fluxes, accumulation and metabolism to the great extent.

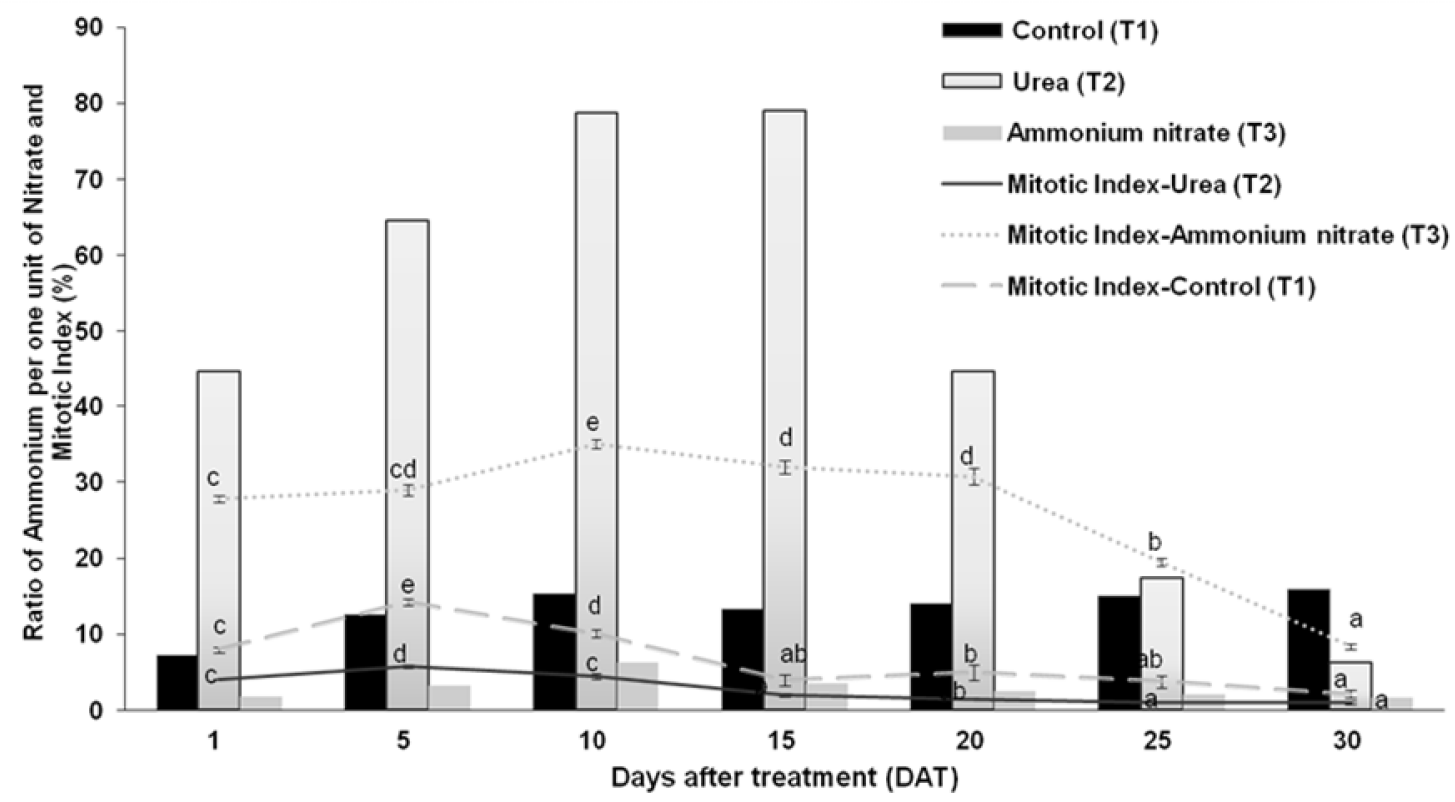

Fig 3: Graph depicting relationship between $\mathrm{NH}_{4}{ }^{+} \mathrm{N}^{-}$and $\mathrm{NO}_{3}{ }^{-} \mathrm{N}$ ratio $\left(\mathrm{NH}_{4}{ }^{+}-\mathrm{N}\right.$ per unit $\left.\mathrm{NO}_{3}{ }^{-} \mathrm{N}\right)$ with mitotic index (\%) in different treatments. Data for mitotic index are means $\pm \mathrm{SE}$ of three replicates and bars with different letters are signiûcantly different at $p \leq 0.05$ as determined by Duncan's multiple range test. 
Temporal Monitoring and Assessment of Inorganic Nitrogen Content of Soil due to Nitrogen Fertilizers and their Related...

They also showed that net $\mathrm{N}$-acquisition and $\mathrm{N}$-translocation was enhanced when both the inorganic form of $\mathrm{N}$ was provided. However, it has been observed that plants show preference for the form of $\mathrm{N}$ available (Britto and Kronzucker, 2013) though depends on certain factors like, soil $\mathrm{pH}$, aeration of soil etc. (Masclaux-Daubresse et al., 2010). Many reports have suggested the role of synergism between $\mathrm{NH}_{4}^{+}$ and $\mathrm{NO}_{3}$ - nutrition (Marschner, 2012). Lastly if we compare all the treatments, drawback/constraint with urea (T2) is that $\mathrm{NH}_{4}{ }^{+}-\mathrm{N}$ levels are very high initially till one week contributing to growth to certain limit beyond which it causes toxic effects as seen in present and previous studies. The reason is that here nitrate is not contributing to alleviate the toxic effects of its counter ion. In ammonium nitrate, the advantage is availability of both the ions for selective uptake by plants as well as counter balance of each other's ill effects and synergistic enhancement of growth.

\section{CONCLUSION}

Present study gives an idea about the cytotoxic effects of two fertilizers, urea and ammonium nitrate. Urea fertilizer provides single source of nitrogen i.e., $\mathrm{NH}_{4}{ }^{+} \mathrm{N}$ which shows cytotoxic effects, whereas double salt fertilizer ammonium nitrate yields both ions on ionization, which nullify each other's negative effects. Such studies are warranted in the field of agriculture management, where input of fertilizers is meant to increase the yield.

\section{ACKNOWLEDGEMENT}

The authors thank the Council of Scientific and Industrial Research (CSIR) and University Grant Commission (UGC), India for financial assistance. The authors are grateful and dedicate this manuscript to Late Prof. Alka Srivastava under whose guidance the work was successfully accomplished.

\section{REFERENCES}

Arora, K., Singh, N., Srivastava, S., Srivastava, A. (2014). Evaluation of genotoxic risks due to temporal changes in soil urea: Using Allium cepa L. root tip bioassay. Cytologia. 79: 85-93.

Babourina, O., Voltchanskii, K., McGann, B., Newman, I., Rengel, Z. (2007). Nitrate supply affects ammonium transport in canola roots. Journal of Experimental Botany. 58: 651-658.

Bar-Yosef, B., Mattson, N.S., Lieth, H.J. (2009). Effects of $\mathrm{NH}_{4}: \mathrm{NO}_{3}$ : urea ratio on cut roses yield, leaf nutrients content and proton efflux by roots in closed hydroponic system. Scientia Horticulturae. 122: 610-619.

Bianchi, J., Fernandes, C.C.T., Marin-Morales, M.A. (2016). Induction of mitotic and chromosomal abnormalities on Allium cepa cells by pesticides imidacloprid and sulfentrazone and the mixture of them. Chemosphere. 144: 475-483.

Bindraban, P.S., Dimpkpa, C., Nagarajan, L., Roy, A., Rabbinge, R. (2015). Revisiting fertilizers and fertilization strategies for improved nutrient uptake by plants. Biology and Fertility of Soils. 51: 897-911.

Bittsánszky, A., Pilinszky, K., Gyulai, G., Komives, T. (2015). Overcoming ammonium toxicity. Plant Science. 231: 184-190.
Bremner, J.M. (1965). Total Nitrogen. In: Methods in Soil Analysis: Chemical and Microbiological Properties Part II. [Black, C.A. (ed)]. American Society of Agronomy, Madison, USA.

Britto, D.T. and Kronzucker, H.J. (2002). $\mathrm{NH}_{4}{ }^{+}$toxicity in higher plants: a critical review. Journal of Plant Physiology. 159: 567-584.

Britto, D.T. and Kronzucker, H.J. (2013). Ecological significance and complexity of $\mathrm{N}$-source preference in plants. Annals of Botany. 112: 957-963.

Britto, D.T. and Kronzucker, H.J. (2005). Plant nitrogen transport and its regulation in changing soil environments. Journal of Crop Improvement. 15: 1-23.

Cabrera, R.I. (2001). Effect of $\mathrm{NaCl}$ salinity and nitrogen fertilizer formulation on yield and nutrient status of roses. Acta Horticulturae. 547: 255-260.

Esteban, R., Ariz, I., Cruz, C., Moran, J.F. (2016). Review: mechanism of ammonium toxicity and the quest for tolerance. Plant Science. 248: 92-101.

Fashaho, A., Musandu, A. O., Lelei, J.J., Mwonga, S.M., Ndegwa, G.M. (2020). Effects of nitrogen and phosphorus fertilizer rates on maize (Zea mays L.) growth and yields in terraced lands of medium and high altitude regions of rwanda. Agricultural Science Digest. 40(3): 242-248.

Firbas, P. and Amon, T. (2013). Allium chromosome aberration test for evaluation effect of cleaning municipal water with Constructed Wetland (CW) in Sveti Tomaž, Slovenia. Journal of Bioremediation and Biodegradation. 4: 189.

Fiskesjo, G. (1985). The Allium test as a standard in environmental monitoring. Hereditas. 102: 99-112.

Hinsinger, P., Plassard, C., Tang, C., Jaillard, B. (2003). Origins of root induced $\mathrm{pH}$ changes in the rhizosphere and their responses to environmental constraints; A review. Plant Soil. 248: 43-59.

Khaldi, F., Berrebbah, H., Djebar, M.R. (2012). Toxic effect of fertilizers on inferior plants resed as biological models. In: Proc. International Conference on Applied Life Sciences (ICALS 2012), Turkey. pp. 205-210.

Kronzucker, H.J., Britto, D.T., Davenport, R., Tester, M. (2001). Ammonium toxicity and the real cost of transport. Trends in Plant Science. 6: 335-337.

Kronzucker, H.J., Siddiqi, M.Y., Glass, A.D.M., Kirk, G.J.D. (1999). Nitrate-ammonium synergism in rice: a subcellular analysis. Plant Physiology. 119: 1041-1046.

Kumari, S., Ghosh, G., Meshram, M.R. (2021). TSS, yield and energetics of stevia as influenced by nitrogen levels and spacing under eastern U.P. conditions. Agricultural Science Digest. 41(2): 319-323.

Li, S-X., Wang, Z-H., Stewart, B.A. (2012). Responses of Crop Plants to Ammonium and Nitrate N. In: [Sparks, D.L. (ed)]. Advances in agronomy, Academic press, USA. 118: 205-398.

Liu, Y., Lai, N., Gao, K., Chen, F., Yuan, L., Mi, G. (2013). Ammonium inhibits primary root growth by reducing the length of meristem and elongation zone and decreasing elemental expansion rate in the root apex in Arabidopsis thaliana. PLOS ONE. 8: 61031.

Marschner, P. (2012). Marschner's Mineral Nutrition of Higher Plants. $\left(3^{\text {rd }}\right.$ ed). Elsevier Publishers, Oxford, UK. 
Temporal Monitoring and Assessment of Inorganic Nitrogen Content of Soil due to Nitrogen Fertilizers and their Related...

Masclaux-Daubresse, C., Daniel-Vedele, F., Dechorgnat, J., Chardon, F., Gaufichon, L., Suzuki, A. (2010). Nitrogen uptake, assimilation and remobilization in plants: Challenges for sustainable and productive agriculture. Annals of Botany. 105: $1141-1157$.

Mittler, R. (2002). Oxidative stress, antioxidants and stress tolerance. Trends in Plant Science. 7: 405-410.

Oh, K., Kato, T., Xu, H.L. (2008). Transport of nitrogen assimilation in xylem vessels of green tea plants fed with $\mathrm{NH}_{4}-\mathrm{N}$ and $\mathrm{NO}_{3}-\mathrm{N}$. Pedosphere. 18: 222-226.

Okushima, Y., Inamoto, H., Umeda, M. (2011). A high concentration of nitrate causes temporal inhibition of lateral root growth by suppressing cell proliferation. Plant Biotechnology. (Tsukuba). 28: 413-416.

Peech, M., Alexander, L.T., Dean, L.A., Reed, J.F. (1947). Methods of Soil Analysis for Soil-fertility Investigations, USDA, Washington D.C.

Qin, C., Yi, K.K., Wu, P. (2011). Ammonium affects cell viability to inhibit root growth in Arabidopsis. Journal of Zhejiang University-SCIENCE B. 12: 477-484.

Rogato, A., Apuzzo, E.D., Barbulova, A., Omrane, S., Parlati, A., Carfagna, S., Costa, A., Schiavo, F.L., Esposito, S., Chiurazzi, M. (2010). Characterization of a developmental root response caused by external ammonium supply in Lotus japonicas. Plant Physiology. 154: 784-795.

Sharma, A.K. and Sharma, A. (1980). Chromosome techniquetheory and practice. Butterworths, London.
Verma, S. and Srivastava, A. (2017). Cytomorphologic parameters in monitoring cytogenotoxic effects of fertilizer in Allium cepa L. Environmental Monitoring and Assessment. 189: 159.

Verma, S. and Srivastava, A. (2018a). Cyto-genotoxic consequences of carbendazim treatment monitored by cytogenetical analysis using Allium root tip bioassay. Environmental Monitoring and Assessment. 190: 238.

Verma, S. and Srivastava, A. (2018b). Morphotoxicity and cytogenotoxicity of pendimethalin in the test plant Allium cepa L. - A biomarker based study. Chemosphere. 206: 248-254.

Verma, S., Arora, K. and Srivastava, A. (2016). Monitoring of genotoxic risks of nitrogen fertilizers by Allium cepa $\mathrm{L}$. mitosis bioassay. Caryologia. 69: 343-350.

Wang, M.Y., Siddiqi, M.Y., Ruth, T.J., Glass, A.D.M. (1993). Ammonium influx by rice roots. II. Kinetics of ${ }^{13} \mathrm{NH}_{4}{ }^{+}$influx across the plasmalemma. Plant Physiology. 103: 1259-1267.

Yang, S., Hao, D., Jin, M., Li, Y., Liu, Z., Huang, Y. Chen, T., Su, Y. (2020). Internal ammonium excess induces ROS-mediated reactions and causes carbon scarcity in rice. BMC Plant Biology. 20: 143.

Yin, M., Li, Y., Xu, Y. (2017). Comparative effects of nitrogen application on growth and nitrogen use in a winter wheat/ summer maize rotation system. Journal of Integrative Agriculture. 16(10): 2062-2072.

Zou, K.H., Tuncali, K., Silverman, S.G. (2003). Correlation and simple linear regression. Radiology. 227: 617-622. 